\title{
Efficiency of using the rangeland hydrology and erosion model for assessing the degradation of pastures and forage lands in Aydarly, Kazakhstan
}

\author{
Maira Kussainova a,*, Kenneth E. Spaeth b, Ermekkul Zhaparkulova c \\ a Sustainable Agriculture Center, AgriTech Hub KazNAU, Kazakh National Agrarian University, Almaty, Kazakhstan \\ b Central National Technology Support Center, Natural Resources Conservation Service (NRCS), \\ United States Department of Agriculture (USDA), Texas. USA \\ c Department of Water resources and Reclamation, Kazakh National Agrarian University, Almaty, Kazakhstan
}

\section{Article Info}

Received : 11.08 .2019

Accepted : 24.03.2020

\begin{abstract}
This study examined the use of a novel web-tool for Rangeland Hydrology and Erosion Model (RHEM) as a prediction runoff and erosion as a function of vegetation structure and behavior of different plant community phases and the amount of coverage for the different states in the Aydarly village of Jambul district of Almaty province. US Department of Agriculture experts and Kazakhstani scientists jointly conducted this study, where, based on the results, they received recommendations on improving rangeland. Results suggested that the model could be further improved with additional measured experimental data on infiltration, runoff, and soil erosion within key ecological sites in order to better quantify model parameters to reflect ecosystem changes and risk of crossing interdependent biotic and abiotic thresholds. These additions were further improved and implemented in other regions of Kazakhstan on other projects.
\end{abstract}

Keywords: RHEM, Kazakhstan, Rangeland, Aydarly, soil erosion, pastureland erosion.

(C) 2020 Federation of Eurasian Soil Science Societies. All rights reserved

\section{Introduction}

At all times, the main value of any nation was their land. Land degradation is a significant phenomenon on the world particularly arid, semi-arid and semi-humid terrestrial ecosystem environments due to variety of factors such as through unsustainable land management, and through physical and climatic characteristics. One of the main indicators and commonly used in the land degradation and desertification is the soil quality level (Demirağ Turan et al., 2019). Therefore, the quantity and quality of soil is an important indicator of the sustainable development of each country, which feeds and provides livelihoods for the people (Bekturova and Romanova, 2007).

For the population of Kazakhstan, due to arid climatic conditions and scarcity of water resources, land use problems have always been quite acute. The people used the best land use methods to obtain maximum efficiency and at the same time preserve the fertility of the land, which is important for the country (Strategic Measures, 2015; Bekturova and Romanova, 2007; Final report, 2018). The main areas of land use were farming and animal husbandry (FAO, 2010). For those who are interested in working in cooperation with feedlots and meat processing plants in the development of farms in beef cattle and sheep farming is an opportunity to increase export potential for the long term. In Kazakhstan, the State Agro-Industrial Complex Development Program for 2017-2021 was adopted by the Ministry of Agriculture to implement long-term sectoral programs for the development of livestock industries, which currently encourages pasture owners and stakeholders to promote and manage pastures (FAOLEX, 2017). The aridity of the climate, the nature of soils and the existing biodiversity of pasture vegetation in Kazakhstan historically determined a peculiar

\footnotetext{
${ }^{*}$ Corresponding author.

Sustainable Agriculture Center, AgriTech Hub KazNAU, Kazakh National Agrarian University, Almaty, 050010 Kazakhstan

Tel.: +77071785588

e-ISSN: 2147-4249

E-mail address: mairakussainova@gmail.com DOI: 10.18393/ejss.708898
} 
form of nature management and livelihoods of the population as nomadic cattle breeding on seasonal pastures. Pasture feed in the south-east of Kazakhstan makes up 70-75\% of the annual ration of grazed animals. Therefore, the welfare of the rural population with livestock directly depends on the condition of grazing sites (PF, 2007). The most convenient for changing pastures were natural pasture complexes. One of these classic complexes is Alatau-Pribalkhashsky, combining mountain summer pastures, winter sand pastures and flat spring-autumn pastures between them, using the example of the Aydarly rural district.

The complex interactions of climate, topography, soil, vegetation, and human economic activity depend on the nature and intensity of erosion processes in the pasture soil, which contribute to a general decrease in the intensity of water erosion processes and increased deflation in unprotected areas of the territory. Pasture degradation, namely a decrease in vegetation cover, changes in vegetation composition and associated loss of ecosystem productivity, are likely consequences of cyclical climatic events (UNCCD, 1994). Land degradation in Kazakhstan has a serious socio-economic impact on living standards and public health, especially on socially vulnerable groups. One of the main reasons for the impact on degradation is a decrease in efficiency and a high risk for cattle breeding as a result of pasture degradation and lack of feed. In many lands, there is a tendency toward a deterioration of the state of pastures in places of constant concentration of livestock (PF, 2007; Shimyrbaeva, 2013). This is primarily due to the areas of pastures used and the number of livestock grazed on them, the productivity and nutritional value of pasture, irrigation of pastures, etc. Using new technologies for forecasting erosion, it is possible to simulate complex interactions between the characteristics of the vegetation cover, soil properties, hydrological and erosion processes on pastures (Nearing, 2011a,b). The purpose of this article is to describe the results of the study using a web-based tool for modeling hydrology and pasture erosion by presenting in detail the structure of the mathematical model and reporting on the results of applying the model (Hernandez, 2017). The pasture hydrology and erosion assessment tool is designed to provide reliable, scientifically sound technologies for modeling and predicting runoff and erosion rates on rangelands, as well as to help assess the impact of pasture conservation practices (Herrick, 2009, 2017).

The approach used in this study has some aims: (i) to assess forage resources of a rangeland using a tool, measuring and driving research data on 13 indicators on a small semi-arid plain spring-autumn pasture of Aydarly rural district, (ii) to identify resource requirements local livestock farms through research interviews; (iii) to study the improvement of tool performance; and (4) to provide guidance for interested farmers to participate in more detailed land conservation and management plans.

\section{Material and Methods}

\section{Study area}

The current investigation involved sampling and analyzing from Aydarly village $\left(44^{\circ} 11^{\prime} 58.39^{\prime \prime} \mathrm{N}\right.$, 75'50'31.57"E), lying on the edge (Kazakh: jeek) between the desert-steppe to the south, and the Sarytaukum ("yellow mountain of sand") desert to the north. Aydarly lies in the northern part of Jambul district of Almaty province, in the south east of the country (Figure 1).

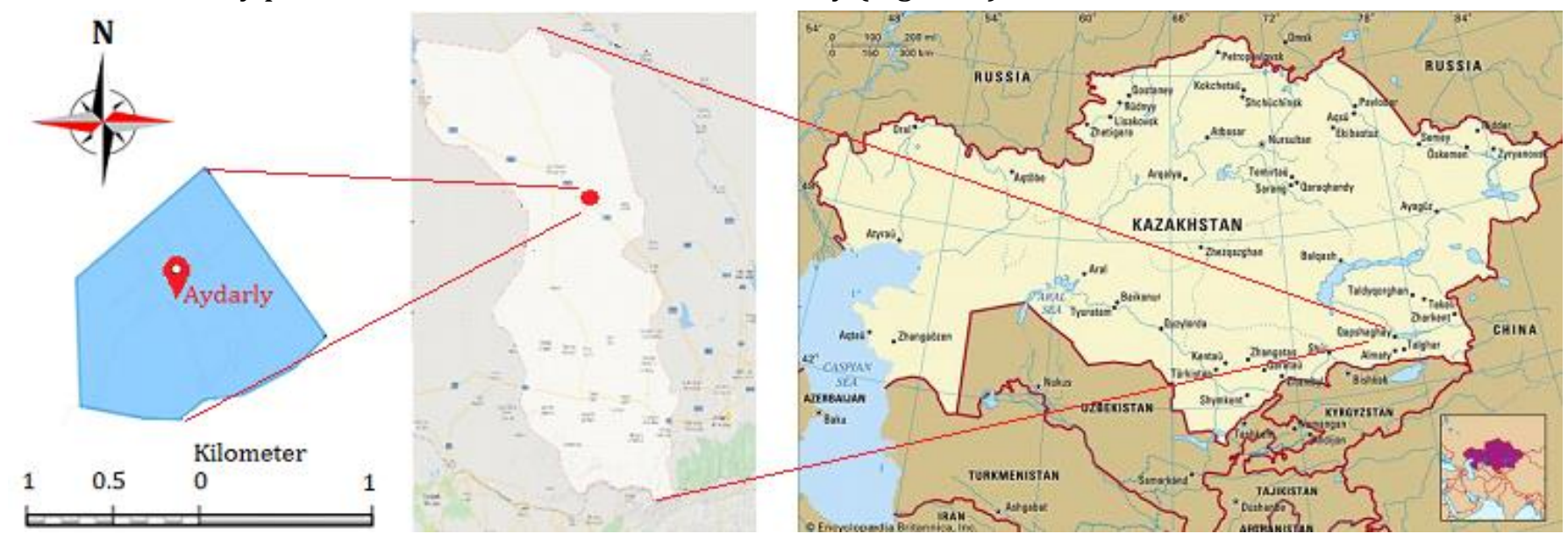

Figure 1. Location of the study site in Kazakhstan

The total pasture area of the rural district as of September 2017 is 110,062 ha. General features and location of the studied area are shown in Figure 1. The average annual precipitation is $230 \mathrm{~mm}$, while temperatures range from a minimum $-35^{\circ} \mathrm{C}$ in January to a maximum of $45^{\circ} \mathrm{C}$ in July. Vegetation in the northern sand dune area of the Sarytaukum is mainly composed of shrubs, Haloxylon persicum, Artemisia species, small shrubs of Salsola and Kochia, and in spring, ephemeral grasses of which Carex physodes is the most important. Some 20 
$\mathrm{km}$ south of the village lie some low hills with springs, dominated by Artemisia species and ephemeral spring grasses (Kerven, 2008).

\section{Method}

This current study consists of 3 phases, which was divided the 9 planning stages used by scientists when working with farmers in the research area (Figure 2).

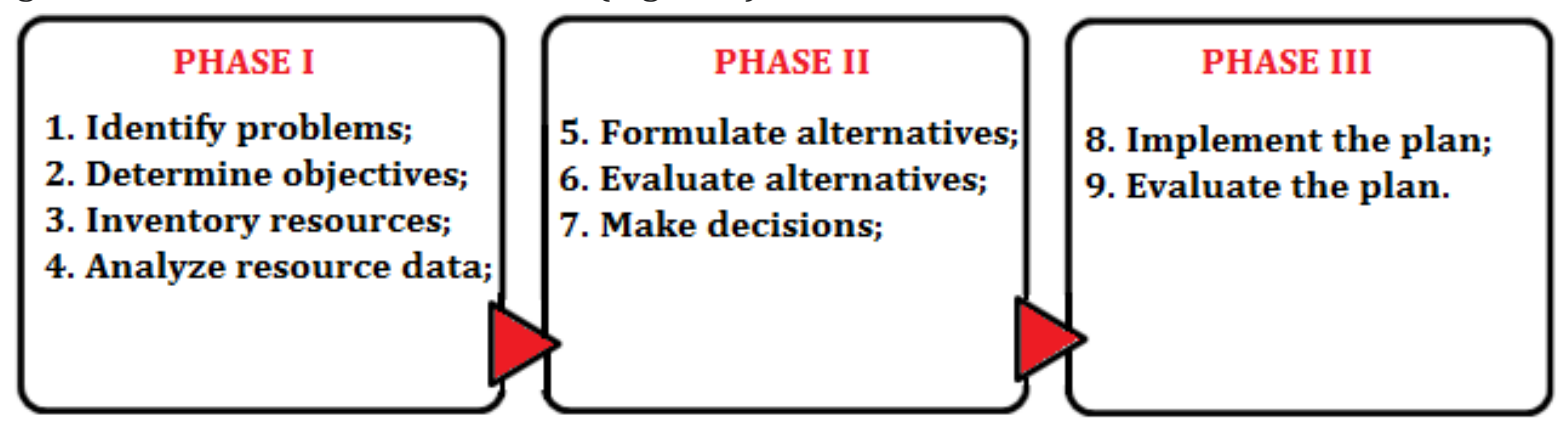

Figure 2. Farm Visit Objectives

For the main assessment, the RHEM model was used, which is a comprehensive assessment tool, rangeland degradation estimates runoff, soil loss, speed and volume of soil transported from wastewater and the timeline of a single precipitation event. For the model, we entered data on 13 parameters presented in Table 1 , which as a result provides information for assessing erosion of rangelands. The group of soil parameters in Table 1 is calculated using the equations of pedoprotection (parameter estimates) obtained from Nearing et al. $(2011 a, b)$. An important aspect of the model regarding the use of pasture by managers is that RHEM is parameterized on the basis of four groups of classification of plant life forms (bunchgrass, shrub, sodgrass, and annual grass /forbs).

Table 1. Standard Indicators included in the Rangeland Health protocol and attribute (soil and site stability, hydrologic function, and/or biotic integrity) to which each indicator applies. The " $\mathrm{X}$ " indicates that the indicator is applied to the attribute.

\begin{tabular}{|c|c|c|c|}
\hline \multirow[b]{2}{*}{ Rangeland Health Indicator } & \multicolumn{3}{|c|}{ Rangeland Health Attribute } \\
\hline & $\begin{array}{l}\text { Soil and Site } \\
\text { Stability }\end{array}$ & $\begin{array}{l}\text { Hydrologic } \\
\text { Function }\end{array}$ & $\begin{array}{c}\text { Biotic } \\
\text { Integrity }\end{array}$ \\
\hline 1. Rills & $\mathrm{X}$ & $\mathrm{X}$ & \\
\hline 2. Water flow patterns & $\mathrm{X}$ & $\mathrm{X}$ & \\
\hline 3. Pedestals and/or Terracettes & $\mathrm{X}$ & $\mathrm{X}$ & \\
\hline 4. Bare ground & $\mathrm{X}$ & $\mathrm{X}$ & \\
\hline 5. Gullies & $\mathrm{X}$ & $\mathrm{X}$ & \\
\hline 6. Wind scoured, blowouts, and/or deposition areas & $\mathrm{X}$ & & \\
\hline 7. Litter movement & $\mathrm{X}$ & & \\
\hline 8. Soil surface resistance to erosion & $\mathrm{X}$ & $\mathrm{X}$ & $\mathrm{X}$ \\
\hline 9. Soil surface loss or degradation & $\mathrm{X}$ & $\mathrm{X}$ & $\mathrm{X}$ \\
\hline $\begin{array}{l}\text { 10. Plant community composition and distribution relative to } \\
\text { infiltration and runoff }\end{array}$ & & $\mathrm{X}$ & \\
\hline 11. Compaction layer & $\mathrm{X}$ & $\mathrm{X}$ & $\mathrm{X}$ \\
\hline 12. Functional/structural groups & & & $\mathrm{X}$ \\
\hline 13. Plant mortality/decadence & & & $\mathrm{X}$ \\
\hline 14. Litter amount & & $\mathrm{X}$ & $\mathrm{X}$ \\
\hline 15. Annual aboveground production & & & $\mathrm{X}$ \\
\hline 16. Invasive plants & & & $\mathrm{X}$ \\
\hline 17. Reproductive capability of perennial plants & & & $\mathrm{X}$ \\
\hline
\end{tabular}

\section{Results and Discussion}

As a result of research on methodological recommendations, a calculation was made of the rate of harvesting feed in livestock. Since the plot has rangeland with different vegetation conditions, higher and lower productivity levels, the feed calculation for the selected plot was not carried out for the whole farm. The calculations give an example of the significance of how the team planned a series of tasks to determine farm production and throughput of all livestock.

The initial assessment of the stock level for this site was carried out by various types of livestock: These are initial calculations that require adjustment in accordance with annual climatic data, monitoring the 
performance of animals and the grazing regime in the pasture. Using half of the production $\left(1.982 \mathrm{~kg}^{-h a^{-1}}\right)$ additionally provides an opportunity for about 15-25\% of the yield of livestock waste with food.

In Table 2, we can estimate the calculation of the annual feed requirements for animal feed and livestock feed. The calculation is carried out in such a way that half of the production is $1.982 \mathrm{~kg}^{-h^{-1}} \mathrm{x} 50 \%$ utilization rate $=991 \mathrm{~kg} \cdot \mathrm{ha}^{-1} \mathrm{x} 15 \%$ lack of use efficiency, which leaves about $842.4 \mathrm{~kg} \mathrm{ha}^{-1}$ aft on an annual basis. According to the calculation results, an adult cow (454 kg) with a calf up to 6 months eats $4980 \mathrm{~kg}$ of dry matter per year. Thus, to provide nutrition for several years, about 6 ha per year is needed for one mature cow and calf. A mature horse $(500 \mathrm{~kg})$ eats $5,388 \mathrm{~kg}$ of feed per year. Therefore, 6.4 ha of feed per horse is needed annually. For a $68 \mathrm{~kg}$ sheep with a lamb (up to 2 months), it is estimated that about $69.4 \mathrm{~kg}$ of feed (dry weight) per month is required. If the plot has 842.4 kg.ha-1 of feed, then: $842.4 \mathrm{~kg}^{-1} \mathrm{ha}^{-1}$ of products $/ 69.4$ $\mathrm{kg}$ (sheep consumption per month) would mean that 1 ha would support 12 sheep and lambs (in the first 2 months of life) for one month or 1 hectare per sheep and lamb for 12 months (1 year) (Figure 3).

Table 2. Forage Needs for Livestock

\begin{tabular}{lrrr} 
& \multicolumn{3}{c}{ Air-dry weight of forage consumed } \\
\cline { 2 - 4 } & Day, kg & month, kg & Year, kg \\
\cline { 2 - 4 } Cow, dry (1000 lbs.) (454 kg cow)* & 11.6 & 347.0 & 4164.0 \\
Cow (1000 lbs.) (454 kg cow), with calf to 6 months & 13.6 & 415.0 & 4980.4 \\
Cow (1100 lbs.) (498 kg), with calf to 4 months & 15.0 & 449.1 & 5388.7 \\
Cow (1200 lbs.) (544 kg), with calf to 4 months & 16.3 & 489.9 & 5878.6 \\
Cow (1300 lbs.) (589 kg) with calf to 4 months & 17.7 & 530.7 & 6368.4 \\
Calf, 4 months to weaning & 4.1 & 122.5 & 1469.6 \\
Yearling cattle, 7-12 months & 8.8 & 265.4 & 3184.2 \\
Yearling cattle, 12-17 months & 10.2 & 306.2 & 3674.1 \\
Heifers, 18-24 months & 11.8 & 353.8 & 4245.6 \\
Bulls, 12-24 months & 16.3 & 489.9 & 5878.6 \\
Bulls, mature (1850 lb. 839 kg. average) & 20.4 & 612.3 & 7348.2 \\
Horse, yearling & 10.2 & 306.2 & 3674.1 \\
Horse, 2 year old & 13.6 & 415.0 & 4980.4 \\
Horse, mature (1100 lbs. 500 kg) & 15.0 & 449.1 & 5388.7 \\
Sheep, mature lactating ewe (150 lbs. 68 kg), with lamb, & 2.3 & 69.4 & 832.8 \\
less than 2 months & 2.0 & 61.2 & 734.8 \\
Sheep, mature non-lactating ewe & 0.8 & 24.5 & 293.9 \\
Lamb, 2 months to weaning & 1.6 & 49.0 & 587.9 \\
Lamb, weaned to yearling & 2.0 & 61.2 & 734.8 \\
Lamb, yearling & 2.3 & 69.4 & 832.8 \\
Ram (200 lbs. 91 kg) & 2.0 & 61.2 & 734.8 \\
Goat, mature & & & \\
\hline
\end{tabular}

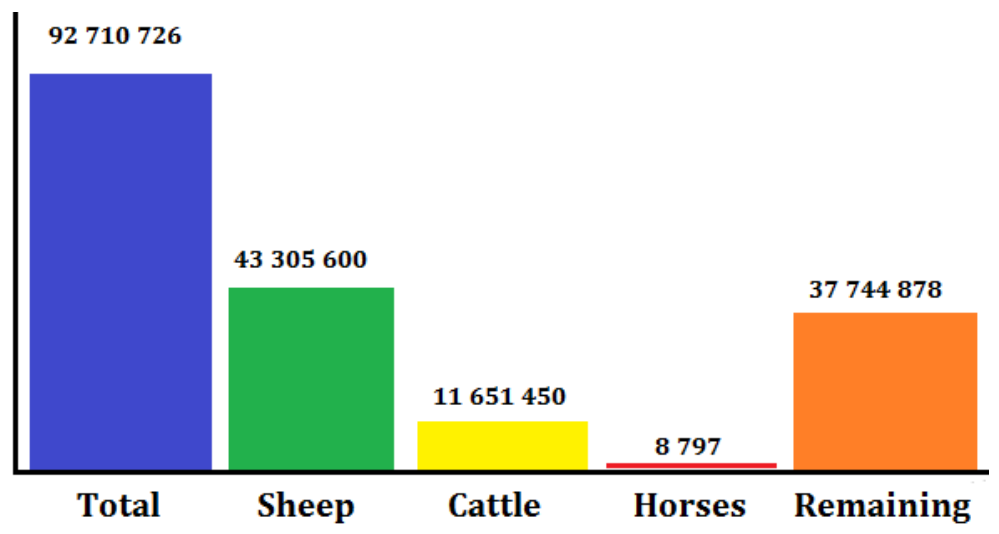

Figure 3. Graph of Estimated total forage and use by current sheep, cow/calf, and horses in Aidarly

In the Aydarly rural district, sheep herds number approximately 52,000 animals, which require uninterrupted supply of full-fledged feeds up to their mature age of about 52,000 ha during the year. Depending on the conservation and sale of the lambs locally, additional land should be set aside to meet their feed requirements. For one separated lamb from 2 months to a year (10 months in assortment), $490 \mathrm{~kg}$ of dry matter feed is required. This will require 0.58 ha per lamb for 2 months (estimated weaning age) to 1 year. Since the possibility of preserving the lamb and the proportion of paired lambs is unknown, it is impossible to calculate the territory needed for the lambs after weaning. However, the above calculations can be used to determine this based on the management of the lambs. For a herd of 2162 cows, 
approximately 13,832 ha is required, provided that the pastures have the same annual feed production to maintain herd productivity and maintain the productivity of the selected site. Approximately 8,800 ha of land are needed to meet both animal characteristics and environmental sustainability requirements for a herd of horses, 1,375 animals. All these initial calculations of the harvest depend on the estimated mass of the animal, breed, feed quality, access to water, climate and topographic aspects of the pasture. In general, it is not recommended to use land with an inclination of more than $30 \%$ in calculations of harvesting speed, but it is possible to use grazing by animals. Areas with slopes of more than $30 \%$ are very susceptible to accelerated soil erosion and loss of productivity if they are severely degraded or simply "knocked down". Rangeland health assessment was assessed using 18 parameters, which are presented in Table 3:

- Soil and site stability is the capacity of a site to limit redistribution of loss of soil resources (including nutrients and organic matter) by wind and water.

- Hydrologic function characterizes the capacity of the site to capture, store, and safely release water from rainfall, run-on and snowmelt (where relevant), to resist a reduction in this capacity and to recover this capacity following degradation.

- Biotic integrity is defined as the capacity of a site to support characteristic functional and structural communities in the context of normal variability, to resist loss of this function and structure caused by disturbance, and to recover following such a disturbance.

Table 3. Rangeland Health Assessment Worksheet

\begin{tabular}{|c|c|c|c|c|c|}
\hline Indicator & NS & SM & $\mathrm{M}$ & ME & EX \\
\hline 1. Rills (SSS,HF) & $\checkmark$ & & & & \\
\hline 2. Water Flow Patterns (SSS,HF) & & $\checkmark$ & & & \\
\hline 3. Plant Pedestals (SSS,HF) & & $\checkmark$ & & & \\
\hline 4. Bare Ground & & $\checkmark$ & & & \\
\hline 5. Gullies (SSS,HF) & $\checkmark$ & & & & \\
\hline 6. Wind Scoured Areas, Blowouts (SSS) & & $\checkmark$ & & & \\
\hline 7. Litter Movement (wind or water) (SSS) & & & $\checkmark$ & & \\
\hline 8. Soil Surface Resistance to Erosion (SSS,HF,BI) & & & $\checkmark$ & & \\
\hline 9. Soil Surface Loss (SSS,HF,BI) & & & $\checkmark$ & & \\
\hline $\begin{array}{l}\text { 10. Plant Community composition and distribution relative to } \\
\text { infiltration and runoff (HF) }\end{array}$ & & & $\checkmark$ & $\checkmark$ & \\
\hline 11. Compaction Layer (SSS,HF,BI) & $\checkmark$ & & & & \\
\hline 12. Plant Functional Group Changes (BI) & & & & $\checkmark$ & \\
\hline 13. Plant Mortality/Decadence (BI) & & $\checkmark$ & & & \\
\hline 14. Litter Amount on Soil Surface (HF,BI) & & $\checkmark$ & & & \\
\hline 15. Annual Plant Production (BI) & & & $\checkmark$ & & \\
\hline 16. Invasive Plants (BI) & & & & & $\checkmark$ \\
\hline 17. Reproductive Capability of Plants (BI) & & $\checkmark$ & & & \\
\hline 18. Native Plant Composition and Diversity (BI) & & & & & $\checkmark$ \\
\hline Soil and Site Stability (Evidence) & & & $\checkmark$ & & \\
\hline Hydrologic Function (Evidence) & & & $\checkmark$ & & \\
\hline Biotic Integrity (Evidence) & & & & $\checkmark$ & \\
\hline
\end{tabular}

NS= None-to-slight change from reference plant community. The reference plant community represents native rangeland with healthy stands of native plants that may include grasses, forbs (non-woody herbaceous plant), and shrub that have not been impacted by severe disturbances such as livestock, machinery, climate extremes.

SM= Slight to Moderate Departure from Reference Conditions

$\mathrm{M}=$ Moderate Departure from Reference Conditions

$\mathrm{ME}=$ Moderate to Extreme from Reference Conditions

EX= Extreme Departure from Reference Conditions

The studies on the state of pastures in Aydarly indicate a complex of negative processes occurring on rangeland s over the past decade. The content of humus (the main indicator of soil fertility) is reduced by $37 \%$; the level of pasture productivity drops to 2.6 times; land is exposed at $63-90 \%$; instead of Kóchia, Artemísia, wheatgrass and other valuable fodder plants, Peganum harmala, Pseudosophora alopecuroides, Melilótus officinális, Ceratocarpus arenarius and other less eaten species appear (Figure 4, 5, 6). 


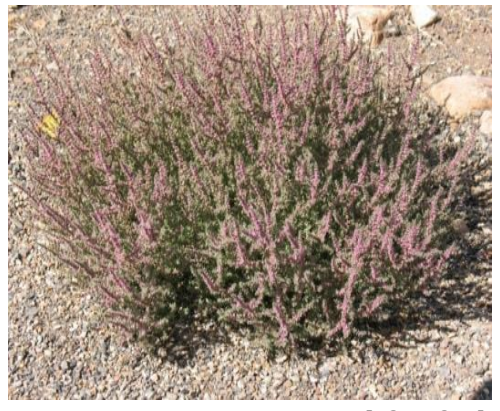

Figure 4. Invasive annaul for forb Sálsola (Russian Thistle)

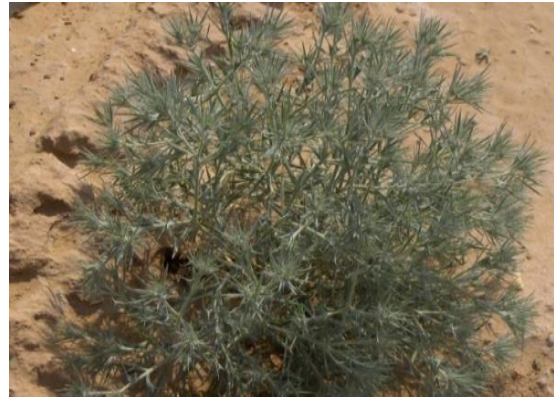

Figure 5. Invasive annual forb Ceratocarpus arenarius

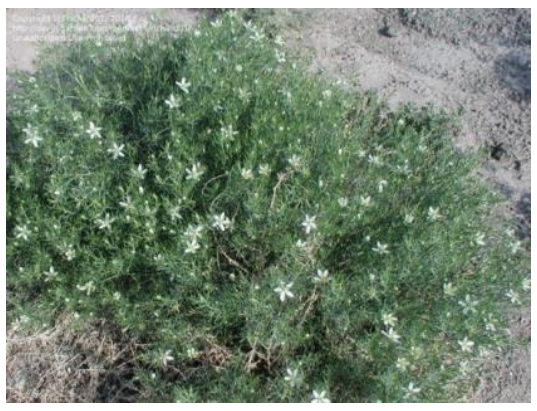

Figure 6. Wild Rue Peganum harmala

The overall superiority of evidence of soil and site stability and hydrological function is the approach to a moderate approach to a moderate yield. The general evidence of biotic integrity is moderately extreme. Corrective action is needed at the research facility before conditions worsen. According to the results of the model shown in Table 4, the projective cover of vegetative vegetation is low. Average annual indicators for Aydarly per year, if precipitation is $163.33 \mathrm{~mm}$, then the washout of the surface horizon is $1.016 \mathrm{~mm}$ per year. In planning a 100-year scenario, degradation is possible at $10.573 \mathrm{~mm}$.

Table 4. Rangeland Hydrology and Erosion Model Web Tool

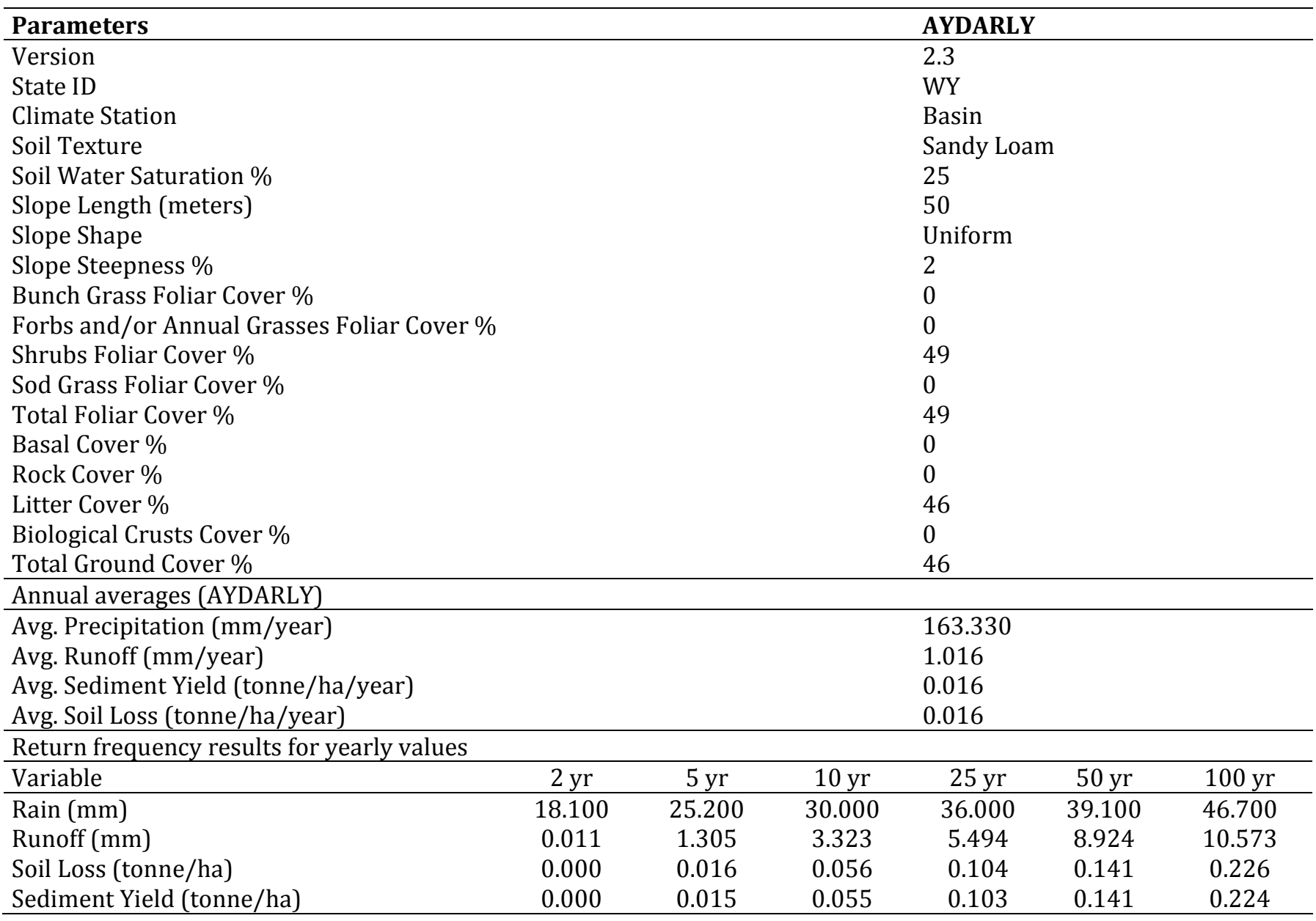

Initial estimates of pasture resources indicate that the area has undergone degradation and requires conservation. A plan is needed for planting crested wheat grass or a hybrid of wheat grass in an existing stand (Figure 7) and a grazing management system for managing restored pasture. Once crested wheat is established, grass will compete with invasive weeds (Sílybum mariánum and Ceratocarpus), and these invasive species will become less numerous and the quantity and quality of the desired feed will be increased.

Reclamation of the contaminated area along with the elimination of disturbing factors, such as overgrazing, is the best way to restore land contaminated with this weed. 
A few kilometers from the highway, the research team observed a very successful sowing of wheat seeds in good condition, although previously there was haymaking on this field. As local economies and resources allow, local shepherds need to develop a sowing program for the most affected pasture areas and continue the sowing program in subsequent years along with the development of a grazing system for proper crop management.

In the spring, cattle and sheep mainly feed on Sálsola until they become flowers and become prickly. Among the vegetation, there is Sálsola, which can accumulate toxic levels of nitrates, which can cause acute respiratory failure and sudden death of cattle and sheep. Dangerous Sálsola milk with a nitrate content of more than 1.0\%; animals can die if they consumed only 0.075 percent of their weight in nitrate. Environmental factors often affect nitrate. For example, nitrate poisoning is more likely if the plant grows in soils with a high nitrogen content, for example, in adhesive tape or in fertilized areas. Excessive shade, lack of water, and stress or physical damage can also increase nitrate levels. Sálsola also contains oxalates, which can lead to kidney failure in cattle and sheep if swallowed.
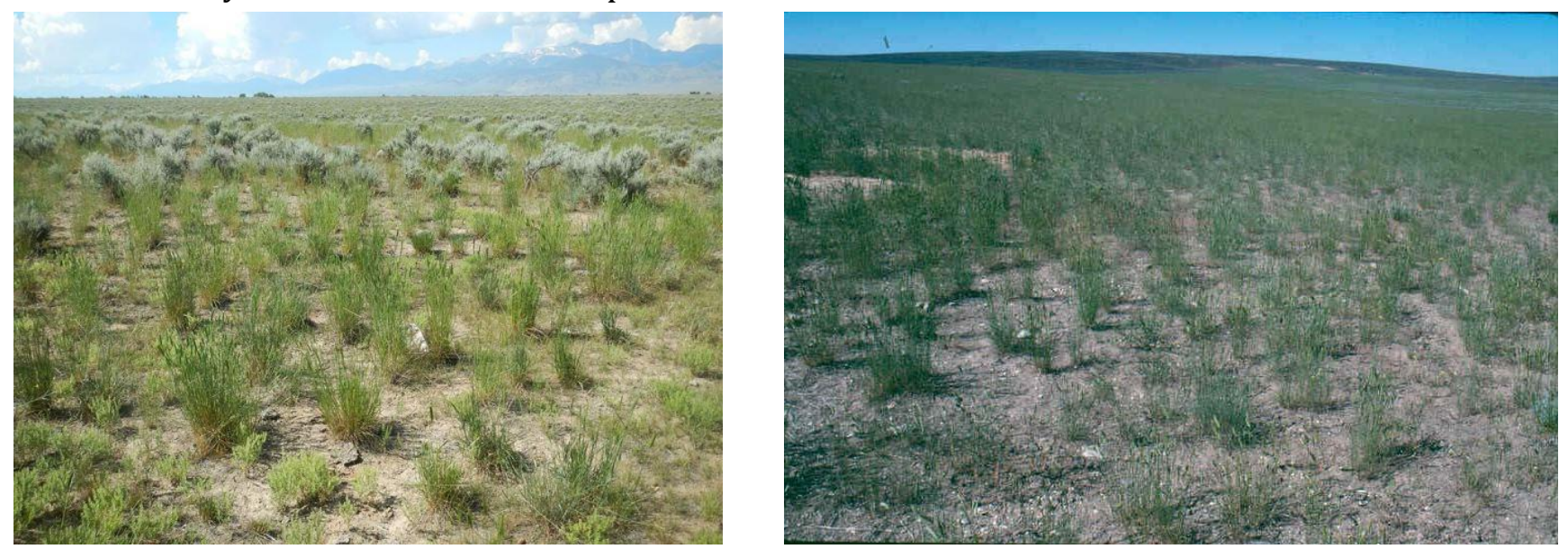

Figure 7. Crested Wheatgrass drilled into sagebrush rangeland to increase forage.

In Aydarly, there is a real opportunity to systematize the use of rangeland by driving away the non-milked part of the livestock to summer mountain pastures and winter sand pastures. It is extremely important to get rid of individual grazing, which is carried out in a radius of no more than $3 \mathrm{~km}$ from the village. The most real and acceptable areas of problems with the use of land resources here may be, first of all:

- Restoration of traditional methods of livestock husbandry when a rotational sparing mode of grazing is used. As is known, large livestock owners with up to 500 heads of small cattle, and especially medium and small livestock breeders in the village of Aydarly, do not take livestock to seasonal pastures due to the lack of watering and conditions for herders. Therefore, it seems necessary to improve the living conditions of shepherds, as well as the reconstruction of previously existing wells on the distillation;

- Since some small and medium-sized cattle owners often do not have the ability to take livestock to the districts, because of the need to leave part of the livestock in the village, it is necessary to strengthen the feed base to prevent overgrazing around the village. This affects the location of the village and all its land in a desert natural zone with an arid climate, where high-quality hay harvesting is limited to the growing season and droughts (Figure 6). Many livestock owners buy livestock feed in neighboring villages. The solution to this issue is complicated by the lack of irrigated land, as the channel through which water came to the irrigated lands of Aydarly village in past periods has not been cleared for several years and is very silty, overgrown with shrubs. The most real way to solve the problem of overgrazing in the village is to switch to the livestock livestock type, traditionally used in these places and being a resource-saving technology in the use of land. In this case, it is necessary to solve the issues of water supply to distant pastures through the restoration of wells.

\section{Conclusion}

In summary, we have presented a new technique new web-tool for Rangeland Hydrology and Erosion Model (RHEM) by a detailed presentation of the structure of the mathematical model and a report on the results of the application of the model. RHEM can predict runoff and erosion as a function of vegetation structure and behavior of different plant community phases and the amount of coverage for the different states. A web-tool for Kazakhstan is a novelty, Aydarly became a pilot study that showed a good result on the assessment of rangeland by territory. Based on the results, we received recommendations for improving Aydarly rangeland. But the implementation of the recommendation requires the active work of members of the local 
government and the community, thanks to which it is possible to strengthen the food supply, improve the socio-economic situation of farmers. To our knowledge, similar tools have not yet been developed in Kazakhstan, but for the perfection to determine an estimate of farm stocks, for future research, drone and satellite imagery will be planned to complement field sampling and identify different types of grassland plant communities. Then, these images are processed on a map of the geographic information system (GIS) of the farm to determine the actual availability of feed by the plant community and pastures. We expect this web-tool to open up an entirely new range of materials and numerous novel rangeland hydrology and erosion estimate device applications.

\section{Acknowledgments}

We are grateful to scientists of the USDA, as well as a scientific researcher of KazNAU for their technical support and cooperation.

\section{References}

Bekturova, G.B., Romanova, O.A., 2007. Information digest: Traditional knowledge in the field of land use in Central Asia. S-Print. Almaty, Kazakhstan. 104 p. [in Russian].

Demirağ Turan İ., Dengiz O., Özkan B. 2019. Spatial assessment and mapping of soil quality index for desertification in the semi-arid terrestrial ecosystem using MCDM in interval type-2 fuzzy environment. Computers and Electronics in Agriculture 164; 104933.

FAO, 2010. Highlights on four livestock sub-sectors in Kazakhstan: Sub-sectoral cross- cutting features and issues. FAO Investment Centre Division, Rome. Italy. 138p. Available at [access date : 11.08.2019]: http://www.fao.org/3/a-bl168e.pdf

FAOLEX, 2017. State Program for the Development of the Agro-Industrial Complex of the Republic of Kazakhstan for 2017-2021. FAOLEX No: LEX-FAOC179522. Available at [access date : 11.08.2019]: http://extwprlegs1.fao.org/docs/pdf/kaz179522.pdf

Final Report, 2018. Final report of Kazakhstan on UNCCD project Land Degradation Neutrality. 2018. LDN, Ministry of Agriculture of Kazakhstan, Astana, Kazakhstan. Available at [access date : 11.08.2019]: https://knowledge.unccd.int/sites/default/files/ldn_targets/2018--1/Kazakhstan\%20LDN\%20TSP\%20Country\%20Report.pdf

Hernandez, M., Nearing, M.A., Al-Hamdan, O.Z., Pierson, F.B., Armendariz, G., Weltz, M.A., Spaeth, K.E, Williams, C.J., Nouwakpo, S.K., Goodrich, D.C., Unkrich, C.L., Nichols, M.H., Collins, C.D.H., 2017. The Rangeland Hydrology and Erosion Model: A dynamic approach for predicting soil loss on rangelands. Water Resources Research 53(11): 9368-9391.

Herrick, J.E., Van Zee, J.W., Havstad, K.M., Burkett, L.M., Whitford, W.G. 2009. Monitoring Manual for Grassland, Shrubland and Savanna Ecosystems. Volume II: Design, supplementary methods and interpretation. USDA-ARS Jornada Experimental Range, Las Cruces, New Mexico, USA. 200p. Available at [access date : 11.08.2019]: https://jornada.nmsu.edu/files/Volume_II.pdf

Herrick, J.E., Van Zee, J.W., McCord, S.E., Courtright, E.M., Karl, J.W., Burkett, L.M., 2017. Monitoring manual for grassland shrubland, and savanna ecosystems. Volume I: Core Methods. USDA-ARS Jornada Experimental Range, Las Cruces, New Mexico, USA. 77p. Available at [access date : 11.08.2019]:

https://jornada.nmsu.edu/files/Core_Methods.pdf

Kerven, C., Shanbayev, K., Alimaev, A., Smailov, K., 2008. Livestock Mobility and Degradation in Kazakhstan's Semi-Arid Rangelands. In: The Socio-Economic Causes and Consequences of Desertification in Central Asia. Behnke, R. (Ed.). NATO Science for Peace and Security Series. Springer, Dordrecht, The Netherlands. pp. 113-140.

Nearing, M.A., Hairsine, P.B., 2011a. The future of soil erosion modelling, In: Handbook of erosion modelling. Morgan, R.P.C, Nearing, M.A. (Eds.), Blackwell Publishing Ltd. Chichester, UK. pp. 387-397.

Nearing, M.A., Wei, H., Stone, J.J., Pierson, F.B., Spaeth, K.E., Weltz, M.A., Flanagan, D.C., Hernandez, M. 2011b. A rangeland hydrology and erosion model. Transactions of the ASAE 54(3): 901-908.

PF, 2007. Local communities in the fight against pastural degradation. UNDP/GM. SGP/GEF. PF "Farmer of Kazakhstan". [in Russian].

Shimyrbaeva, G., 2013. Stop pasture degradation. Kazakhstanskaya Pravda, Almaty. Available at [access date : 11.08.2019]: https://www.kazpravda.kz/news/ekonomika/ostanovit-degradatsiu-pastbishch

Strategic Measures, 2015. Strategic measures to combat desertification in the Republic of Kazakhstan till 2025. Astana, Kazakhstan. 93p. [in Russian]. Available at [access date : 11.08.2019]: https://www.undp.org/content/dam/kazakhstan/docs/research-and-publications/New_Vestka_part_1.pdf

UNCCD, 1994. 10. United Nations Convention to Combat Desertification in those Countries Experiencing Serious Drought and/or Desertification, Particularly in Africa. Paris, Available at [access date : 11.08.2019]: https://treaties.un.org/doc/Treaties/1996/12/19961226\%2001-46\%20PM/Ch_XXVII_10p.pdf 